OPEN ACCESS

Edited by:

Agnieszka Swiatecka-Urban, University of Pittsburgh, United States

Reviewed by:

Sidharth Kumar Sethi,

Medanta The Medicity, India Ahmad Kaddourah, Sidra Medical and Research Center,

Qatar

*Correspondence: Daniel Landau danny_@clalit.org.il

Specialty section:

This article was submitted to

Pediatric Nephrology,

a section of the journal

Frontiers in Pediatrics

Received: 09 October 2017

Accepted: 27 June 2018

Published: 17 August 2018

Citation:

Gurevich E, Israel E, Segev $Y$ and Landau D (2018) Febrile Proteinuria in

Hospitalized Children:

Characterization of Urinary Proteins.

Front. Pediatr. 6:202

doi: 10.3389/fped.2018.00202

\section{Febrile Proteinuria in Hospitalized Children: Characterization of Urinary Proteins}

\author{
Evgenia Gurevich ${ }^{1,2}$, Eytan Israel ${ }^{1,2}$, Yael Segev $^{3}$ and Daniel Landau ${ }^{3,4 *}$ \\ ${ }^{1}$ Soroka University Medical Center, Ben-Gurion University of the Negev, Beersheba, Israel, ${ }^{2}$ Division of Pediatrics, \\ Ben-Gurion University of the Negev, Beersheba, Israel, ${ }^{3}$ Department of Microbiology and Immunology, Ben-Gurion University \\ of the Negev, Beersheba, Israel, ${ }^{4}$ Department of Pediatrics B, Schneider Children's Medical Center, Sackler School of \\ Medicine, Tel Aviv University, Tel Aviv, Israel
}

Background: Transient proteinuria during febrile illness is a common phenomenon. Recent studies have re-examined the pathophysiology of proteinuria and new urinary markers to characterize it, including B7-1 (CD80), which is expressed also in glomerular podocytes and influences the glomerular barrier.

Aim: To investigate the pattern of proteinuria in febrile non-renal diseases, including B7-1.

Methods: We prospectively analyzed urine samples of 44 febrile children and 28 afebrile controls for different protein components: albumin (glomerular marker), $\beta 2$-microglobulin (tubular marker), uromodulin (Tamm Horsfall protein-THP, a renal endogenous protein) and B7-1. Febrile illness was characterized as focal bacterial vs. viral. Exclusion criteria were underlying renal disease, steroid treatment or urinary tract infection.

Results: Elevated urine albumin (64.5 \pm 10.3 vs. $17.8 \pm 4 \mathrm{mg} / \mathrm{g}$, mean \pm S.E.M., $p=0.0009$ ) and $\beta 2$-microglobulin (1.44 \pm 0.34 vs. $0.182 \pm 0.03 \mathrm{mg} / \mathrm{g}$, mean \pm S.E.M., $p=0.005]$ and decreased uromodulin (10.5 \pm 1 vs. $26.7 \pm 2.2$ Arbitrary units, mean \pm S.E.M., $p=0.0001$ ) excretion were found during febrile illness vs. controls. Urine B7-1 was also increased in the febrile group $(0.27 \pm 0.05$ vs. $0.07 \pm 0.01 \mathrm{ng} / \mathrm{ml}$, mean \pm S.E.M., $p=0.001$ ), and was the only marker which was significantly higher in bacterial vs. viral disease.

Conclusions: Febrile proteinuria is not generalized: while proteins of both glomerular and tubular origin increase, uromodulin decreases. Urine B7-1 is increased during fever, more significantly in bacterial infections. Thus, urinary B7-1 may be used as an additional marker to differentiate between febrile states of bacterial vs. viral origin.

Keywords: $\beta 2-$ microglobulin, uromodulin, CD80 (B7-1) protein, albuminuria, proteinuria, fever

\section{INTRODUCTION}

Normal glomerular barrier prevents the filtration of high molecular weight proteins into the Bowman's capsule. Subsequently, proximal tubular reabsorption retrieves proteins of lower molecular weight that escaped glomerular barrier, leading to a minimal amount of protein of circulation origin in urine. In addition, uromodulin, or Tamm Horsfall protein is synthesized 
and partly secreted by the distal tubule and found in urine in normal states $(1,2)$. Transient proteinuria is a common finding in several illness states. It has been described during fever, sepsis, trauma and anaphylaxis, without relation to renal disease (3). Several studies in the past have described transient proteinuria during febrile illness and whether its origin was glomerular or tubular $(4,5)$. However, no studies have been performed on the role of urinary uromodulin in this process. Recent studies have reported new evidence on the pathophysiology of infection related proteinuria, including the role of $\mathrm{B} 7-1$ (CD80) protein, expressed on both circulating leucocytes as well as on glomerular epithelial cells (podocytes). This protein was shown to modulate the podocyte cytoskeleton and influence on glomerular filtration barrier in different proteinuric states $(6,7)$. No studies have been performed to simultaneously examine the involvement of markers of different renal compartments (glomerular, tubular, and endogenously synthesized), including B7-1, in this common phenomenon. We hypothesized that glomerular B7-1 may be upregulated also in transient febrile proteinuria. Therefore, in this study we characterized the type of urinary proteins (albumin, $\beta 2$-microglobulin, uromodulin, and B7-1) in children with febrile proteinuria.

\section{PATIENTS AND METHODS}

The research protocol of the study has been approved by the local Helsinki committee. Study consent was signed by patients' parents. In this prospective study, children with febrile illness (temperature above $38^{\circ} \mathrm{C}$ ) of infectious origin, hospitalized in pediatric wards were enrolled. The exclusion criteria were underlying renal disease, signs of urinary tract infection, or corticosteroid treatment. Children without fever who were hospitalized for elective surgical procedures served as controls. Clinical, laboratory and imaging data were recorded for each patient and the child was finally diagnosed as having a viral [no

TABLE 1 | Demographic characteristics.

\begin{tabular}{|c|c|c|c|}
\hline & Febrile & Afebrile & $P$ value \\
\hline Number & 44 & 28 & \\
\hline Age (mean \pm S.E.M.) & $6.6 \pm 0.79$ & $4.9 \pm 0.72$ & 0.12 \\
\hline Male (\%) & 27 (60\%) & $21(75 \%)$ & NS \\
\hline Background illness & 17 (39\%) & $3(11 \%)$ & 0.02 \\
\hline Previous hospitalization & $18(41 \%)$ & $8(29 \%)$ & NS \\
\hline $\begin{array}{l}\text { Temperature on } \\
\text { admission }\left({ }^{\circ} \mathrm{C}\right) \text {, (mean } \\
\pm \text { S.E.M) }\end{array}$ & $38.6 \pm 0.9$ & & \\
\hline $\begin{array}{l}\text { Maximal temperature } \\
\left({ }^{\circ} \mathrm{C}\right),(\text { mean } \pm \text { S.E.M })\end{array}$ & $39 \pm 0.74$ & & \\
\hline $\begin{array}{l}\text { Hours of fever prior to } \\
\text { admission (mean } \pm \\
\text { S.E.M) }\end{array}$ & $31 \pm 4$ & & \\
\hline $\begin{array}{l}\text { Suspected bacterial } \\
\text { disease (\%) }\end{array}$ & $23(52 \%)$ & & \\
\hline
\end{tabular}

specific focus of infection, normal peripheral blood leucocyte (WBC) count] or a specific bacterial disease.

Urine samples in both study and control groups were collected at the time of admission. Urine samples were checked with Multistix ${ }^{\circledR}$ urinalysis strips for white blood cells, nitrites, protein, blood and specific gravity. Then urine samples were biochemically tested for total protein, albumin (as glomerular injury marker), $\beta 2$-microglobulin (tubular marker), uromodulin (Tamm Horsfall protein-THP, a renal endogenous protein), and B7-1 (CD-80) protein. Urine protein response on the sticks was determined using a semi quantitative determination $(+1$ to +4$)$ method by photometric color test. Urine creatinine was determined using kinetic color test (Jaffé method). Urine albumin was determined by immune turbidometric test. All these tests were performed using an Olympus Life \&[[Inline Image]]Material Science system. Urinary $\beta 2$-microglobulin was determined using Microparticle Enzyme Immunoassay (MEIA)(Abbott Ax SYM, Germany). Tamm Horsfall protein (THP)/uromodulin concentration was analyzed by Western blot analysis using rabbit anti THP antibody (Santa Cruz). Protein expression was quantified densitometrically using Image $J$ software and expressed as arbitrary units (AU). Urine B7-1 (CD80) protein concentration was analyzed using an enzymelinked immunosorbent assay kit (Human sCD80 Instant Elisa Kit, eBioscience, Affymetrix, North America), according to the test protocol. Briefly, after a $3 \mathrm{~h}$ incubation of $50 \mu \mathrm{l}$ urine samples at room temperature, the microwell strips were washed 3 times with approximately $400 \mu$ l wash buffer per well. Then $100 \mu \mathrm{l}$ of TMB substrate solution was pipetted to all wells and the microwell strips were incubated again at room temperature for $10 \mathrm{~min}$. The substrate reaction was stopped by quickly pipetting $100 \mu \mathrm{l}$ of Stop Solution, and then immediately read for absorbance at $450 \mathrm{~nm}$ using a spectro-photometer (SpectraMax Paradigm Multi-Mode Microplate Reader, SoftMax Pro Software, 2014). A standard curve was created by plotting the mean absorbance for each standard concentration on the ordinate against the measured $\mathrm{sCD} 80$ concentration on the abscissa.

Group comparison was performed using standard statistical tests: $t$-test for continuous variables, chi square for categorical values and ANOVA test for comparison of more than 2 continuous variables. Analyzing receiver operating characteristic (ROC curves) was assessed using $p R O C$, an open-source package (8).

\section{RESULTS}

Fifty-six febrile children admitted to the hospital were approached for consent. 12 patients were excluded, 11 because of insufficient amount of urine and one patient because of positive urine culture. Finally 44 febrile children age 2 months -17.7 years, (6.6 \pm 0.79 years, mean \pm S.E.M.) were enrolled and compared with 28 controls age 3 months -16.5 years $(4.9 \pm 0.72$ years, mean \pm S.E.M., $p=0.12)$. There were $27(60 \%)$ males in febrile group vs. $21(75 \%)$ ones in the control group. Seventeen patients (39\%) in febrile group vs. 3 patients (11\%) in the control 
group had some background illness, 18 (41\%) in febrile group vs. $8(29 \%)$ in the control group were previously hospitalized (Table 1). Temperature on admission in febrile group was 38.6 $\pm 0.9^{\circ} \mathrm{C}$, maximal temperature was $39 \pm 0.74^{\circ} \mathrm{C}$, the fever duration prior to admission was similar for both bacterial and viral groups and averaged $31 \pm 4 \mathrm{~h}$ (mean \pm S.E.M). In the study group febrile disease was of bacterial origin in $52 \%$ of cases and of viral origin in $48 \%$. Bacterial diagnoses included: pneumonia (9), rickettsiosis (2), dysentery (4), cellulitis with abscess (1), mastoiditis (1), acute otitis media (1), and occult bacteremia (1). The diagnosis of pneumonia was based on positive findings on chest X-Ray examinations (lobar infiltrate). In one patient blood serologic test was positive for Mycoplasma Pneumonia. Blood cultures were negative in all the patients with pneumonia except one which was positive for Pneumococcus Pneumonia. All patients with pneumonia except two had elevated leucocyte count $\left(24 \pm 2.6^{*} 10^{3} / \mathrm{ul}\right.$, mean \pm S.E.M.). In the patient with rickettsiosis, the diagnosis was based on clinical and laboratory findings and confirmed serologically. Mastoiditis was diagnosed based on clinical findings and leukocytosis $\left(17^{*} 10^{3} / \mu 1\right)$. In the patient with dysentery, stool cultures were positive for shigella (2), salmonella (1), and campylobacter (1). In the patient with an abscess and cellulitis, positive culture for Staph aureus was obtained from the pus. Otitis media was diagnosed clinically, but this patient was also diagnosed with pneumonia, confirmed by a chest X-ray. The diagnosis of occult bacteremia was made based on fever and leukocytosis $\left(20^{*} 10^{3} / \mu \mathrm{l}\right)$. Febrile patients without specific focus of infection and normal peripheral blood leucocyte count were diagnosed as having viral infections.
Urine samples were obtained $31 \pm 4.1 \mathrm{~h}$ (mean \pm S.E.M.) from the beginning of fever. The assessment of different urinary proteins is summarized in Table 2. Multistix ${ }^{\circledR}$ urinalysis strips were positive for protein (in those samples with specific gravity of more than 1010) in 13 out of 43 febrile patients (30\%) and only in 1 patient from the control group $(3.7 \%)$ (two-tailed $\chi^{2}=0.005$ ). In the febrile group urine protein/creatinine ratio was above normal $(200 \mathrm{mg} / \mathrm{g})$ in 32 cases $(72.2 \%)$ vs. 5 cases $(18 \%)$ in the control group $\left(\chi^{2}=0.001\right)$. In the febrile group 27 patients $(60 \%)$ had a urine albumin $\backslash$ creatinine ratio above $30 \mathrm{mg} / \mathrm{g}$ (upper limit of norm) vs. 3 patients in the control group $\left(\chi^{2}<0.005\right)$. Urinary albumin $\backslash$ creatinine ratio in the febrile group was $64.5 \pm 10.3$ $\mathrm{mg} / \mathrm{g}$, mean \pm S.E.M. Of note, the albumin fraction in urine was less than half of the total protein. There was a wide distribution in urine $\beta 2$-microglobulin excretion in the study group: 1.44 $\pm 0.34 \mathrm{mg} \backslash$ g, mean \pm S.E.M. In the control group, urine $\beta 2$ microglobulin was significantly lower $(0.182 \pm 0.03 \mathrm{mg} / \mathrm{g}$, mean \pm S.E.M, $p=0.01$ ) (Table 2). Tamm-Horsfall Protein (THP) excretion in urine was significantly decreased in febrile children vs. control (10.5 \pm 1 vs. $26.7 \pm 2.2$ arbitrary units, mean \pm S.E.M, $p=0.0001)$.

The study group comparison was further subdivided into three groups: afebrile children, patients having febrile disease of bacterial origin (according to above mentioned criteria) vs. non-bacterial origin. As mentioned, total protein excretion was higher in febrile children vs. controls. However, there was no difference between bacterial and nonbacterial febrile groups. Albumin excretion was also elevated in febrile children vs. control without a clear difference between nonbacterial and bacterial groups (Table 2). There was no significant difference in urine

TABLE 2 | Characteristics of proteinuria.

\begin{tabular}{|c|c|c|c|c|c|c|}
\hline \multirow{2}{*}{$\begin{array}{l}\begin{array}{l}\text { Urine values } \\
\text { (mean } \pm \text { S.E.M) }\end{array} \\
\text { Protein/creatinine } \\
(\mathrm{mg} / \mathrm{g})\end{array}$} & \multirow{2}{*}{$\begin{array}{l}\text { Normal value } \\
\\
<200\end{array}$} & \multirow{2}{*}{$\begin{array}{c}\text { Afebrile }(\boldsymbol{n}=\mathbf{2 8}) \\
150 \pm 17\end{array}$} & \multicolumn{2}{|c|}{ Febrile } & \multirow{2}{*}{$\begin{array}{c}\boldsymbol{P} \text {-value AF vs. F } \\
0.0001\end{array}$} & \multirow[t]{2}{*}{$\boldsymbol{P}$-value Bacterial vs. Viral } \\
\hline & & & Total $(n=44)$ & $430 \pm 54.5$ & & \\
\hline & & & Bacterial $(n=23)$ & $480 \pm 83.3$ & & NS \\
\hline & & & Viral $(n=21)$ & $380 \pm 65.3$ & & \\
\hline \multirow{3}{*}{$\begin{array}{l}\text { Albumin/creatinine } \\
(\mathrm{mg} / \mathrm{g})\end{array}$} & $<30$ & $17.8 \pm 4$ & Total $(n=44)$ & $64.5 \pm 10.3$ & 0.0009 & \\
\hline & & & Bacterial $(n=23)$ & $44.7 \pm 8.85$ & & NS \\
\hline & & & $\operatorname{Viral}(n=21)$ & $117.9 \pm 33.2$ & & \\
\hline \multirow{3}{*}{$\begin{array}{l}\beta 2 \mathrm{mgl} / \text { creatinine } \\
(\mathrm{mg} / \mathrm{g})\end{array}$} & $\leq 0.132$ & $0.182 \pm 0.03$ & Total $(n=44)$ & $1.44 \pm 0.34$ & 0.005 & \\
\hline & & & Bacterial $(n=23)$ & $1.218 \pm 0.35$ & & NS \\
\hline & & & $\operatorname{Viral}(n=21)$ & $1.693 \pm 0.58$ & & \\
\hline \multirow{3}{*}{$\begin{array}{l}\mathrm{B} 7-1 \\
(\mathrm{ng} / \mathrm{ml})\end{array}$} & NA & $0.07 \pm 0.01$ & Total $(n=25)$ & $0.27 \pm 0.05$ & 0.001 & \\
\hline & & & Bacterial $(n=11)$ & $0.4 \pm 0.07$ & & 0.002 \\
\hline & & & Viral $(n=14)$ & $0.14 \pm 0.04$ & & \\
\hline \multirow{3}{*}{$\begin{array}{l}\text { Tamm-Horsfall } \\
\text { protein (AU) }\end{array}$} & NA & $26.7 \pm 2.2$ & Total $(n=44)$ & $10.5 \pm 1$ & 0.0001 & \\
\hline & & & Bacterial $(n=23)$ & $7 \pm 1$ & & 0.14 \\
\hline & & & Viral $(n=21)$ & $9.5 \pm 1.3$ & & \\
\hline
\end{tabular}

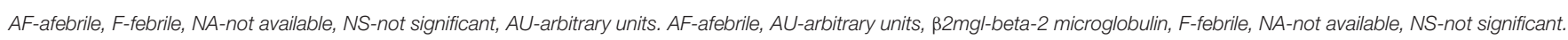




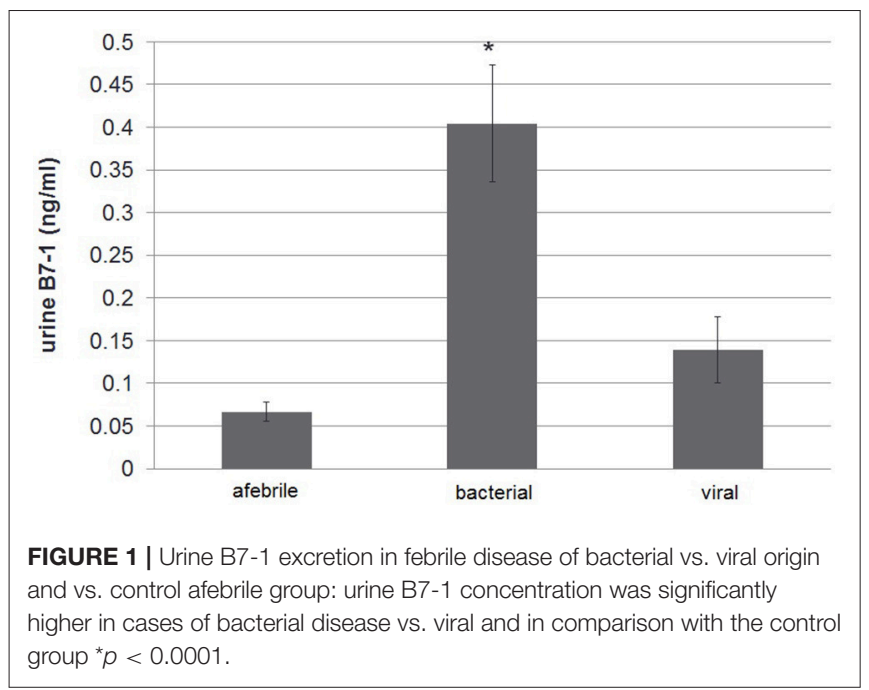

$\beta 2$-microglobulin excretion between bacterial and nonbacterial groups but its excretion was significantly elevated in each of these groups vs. control ( $p<0.05)$. Uromodulin (THP) excretion was lower in the bacterial vs. nonbacterial group, but this difference was not significant $(p=0.14)$. There was a significantly higher excretion of B7-1 in urine in the febrile group vs. afebrile controls $(0.27 \pm 0.05$ vs. $0.07 \pm 0.01 \mathrm{ng} / \mathrm{ml}$, mean \pm S.E.M., $p=0.0001)$. Urine B7-1 concentration was also significantly higher in cases of bacterial disease vs. nonbacterial $(0.4 \pm 0.07$ vs. $0.14 \pm 0.04 \mathrm{ng} / \mathrm{ml}$, mean \pm S.E.M., $p<0.002$ ) (Table 2) (Figure 1). An ROC curve that tests the performance of urine B71 to differentiate between viral and bacterial infections yielded an AUC value $( \pm$ S.E.M) of $0.85 \pm 0.08$ (95\% CI: 0.71-0.99, $p=0.003$ ) (Figure 2). The optimal mathematical point along the curve is a urine B7-1 value of 0.132 , providing a sensitivity of $91.7 \%$ and a specificity of $61.5 \%$. Thus, there was no significant difference in urine excretion of any of the checked proteins in the cases of bacterial vs. viral infection except for urine B7-1 that was significantly higher in the cases of bacterial infections.

\section{DISCUSSION}

In this study we first characterized the type of urinary proteins in children with febrile proteinuria. Elevated urinary total protein (in the mild-non-nephrotic range), urine albumin and $\beta 2$ microglobulin excretion were found in febrile children. Urine B7-1 excretion also was higher in the cases of febrile states. Not all urinary proteins showed a pattern of transient elevation during febrile illness. For example, uromodulin (Tamm-Horsfall protein), that is excreted in urine in normal states, was actually significantly decreased during fever. This protein is secreted by the kidney and is thought to play role in water $\backslash$ electrolyte balance and kidney innate immunity. Studies in Umod knockout mice showed that uromodulin has a defensive role against urinary tract infection (UTI) $(10,11)$, since this protein binds to pathogens of the urinary tract, such as type 1-fimbriated E. coli, and interferes with their binding to uroplakins on the urothelium (12). Several

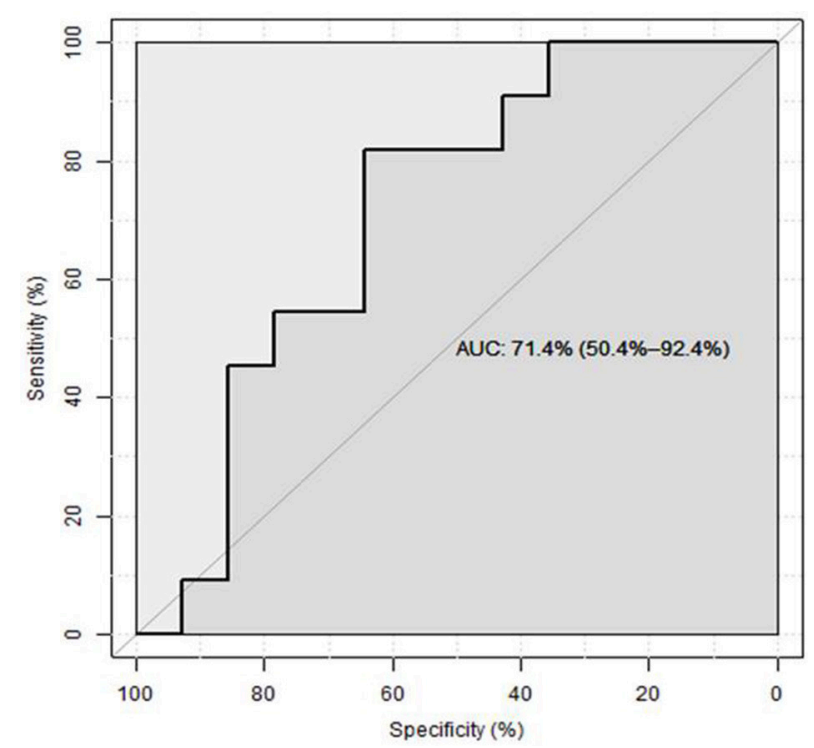

FIGURE 2 | ROC curve assessing the predictive value of urine B7-1 for bacterial infection in febrile children (8)

in vitro studies showed that THP is able to bind to immunityrelated molecules, such as immunoglobulin $\mathrm{G}$, complement 1q, and tumor necrosis factor- $\alpha(9,13,14)$. Uromodulin also acts as a chemoattractant (15) and as a proinflammatory molecule. It interacts with monocytes, neutrophils and myeloid dendritic cells leading to activation of components of the immune system via toll-like receptor 4 (16). The physiological role of this process is still unclear. Saemann et al. hypothesize that uromodulin is released into kidney parenchyma in cases of tubular damage and serves as a signal to activate local immune response to prevent bacterial invasion (16). This unexpected decreased urinary THP excretion during fever can be explained by its excessive excretion into blood, as Prajcer et al. showed that inflammatory damage in thick ascending limb leads to decreased urinary and increased blood uromodulin level (17). Medullary cystic kidney disease type 2 (MIM 603860) and familial juvenile hyperuricemic nephropathy (MIM 162000) are autosomal dominant tubulointerstitial kidney diseases that are due to UMOD gene mutations and are collectively called uromodulin-associated kidney disease (UAKD). Decreased urine uromodulin excretion in these diseases leads to nephropathy, interstitial nephritis, hyperuricemia, renal stone formation and renal insufficiency. In this study, in spite of elevated albumin and $\beta 2$-microglobulin urine excretion during febrile disease, most of urine protein was neither albumin nor $\beta 2$-microglobulin. The increase in urinary albumin excretion suggests that additional high molecular weight proteins may also be excreted, most probably due to a transient disturbance in glomerular barrier. Recent studies have reported new evidences on the pathophysiology of proteinuria of glomerular origin, including the role of B7-1. This protein is expressed in glomerular epithelial cells (podocytes) and influences glomerular anatomical barrier in different proteinuric states. B7-1 influences the actin 
cytoskeleton of podocytes and slit diaphragm organization leading to proteinuria. Both genetic aberrations (e.g., deletion of $\alpha 3$ integrin or nephrin), toxic stimuli (such as PAN induced reactive oxygen species), or direct stimulation of the TLR-4/CD14 receptor on the podocyte can cause B7-1 induction. B7-1 then induces the podocyte's foot process effacement and disruption of the slit diaphragm complex, leading to proteinuria. Reiser et al. (6) also showed rapid upregulation of B7-1 in podocytes and nephrotic-range proteinuria by in vivo exposure to lowdose LPS in wild type and SCID mice. B7-1 knockout mice were protected from this LPS induced nephrotic range proteinuria, suggesting a role of podocyte (and not white blood cell) B71 expression in the pathogenesis of proteinuria. Podocyte's B71 is upregulated in patients with certain glomerular diseases. Positive B7-1 immunostaining was observed in biopsy specimen from patients with recurrent focal segmental glomerulosclerosis (FSGS) a disease associated with severe proteinuria. Yu et al. showed the resolution of nephrotic range proteinuria after B71 inhibition with Abatacept (CTLA-4-Ig) treatment in patients with rituximab-resistant recurrent FSGS and in patients with glucocorticoid-resistant primary FSGS (18), suggesting that B71 can be a target for the treatment of proteinuria. However, these findings have recently been challenged by Baye et al. (19). These new observations led us to explore the possible role of B7-1 in febrile children. As mentioned, B7-1 was found to be the only urine biomarker that was not just significantly higher in febrile disease vs. controls, but also higher in febrile cases of bacterial disease vs. viral origin.

Activation of toll-like receptors (TLRs) is basic in the initiation of innate immunologic response $(20,21)$. For example, exposure to lipopolysaccharide (LPS) induces B7-1 expression via TLR-4 in podocytes, leading to reorganization of its cytoskeleton, foot process effacement and proteinuria. B7-1 acts as a costimulatory molecule in this process, as previously mentioned (6). We suppose that in the cases of bacterial infections toxins or other bacterial components lead to proteinuria via similar mechanism and B7-1 acts as a co-stimulatory molecule in this process, being upregulated and eventually found in urine.

\section{REFERENCES}

1. Devuyst O, Dahan K, Pirson Y. Tamm-Horsfall protein or uromodulin: new ideas about an old molecule. Nephrol Dial Transplant. (2005) 20:1290-4. doi: 10.1093/ndt/gfh851

2. Rampoldi L, Scolari F, Amoroso A, Ghiggeri G, Devuyst O.The rediscovery ofuromodulin (Tamm-Horsfall protein): from tubulointerstitial nephropathy to chronic kidney disease. Kidney Int. (2011) 80:338-47. doi: $10.1038 / \mathrm{ki} .2011 .134$

3. Jensen H, Henriksen K. Proteinuria in non-renal infectious diseases. Acta MedScand. (1974) 196:75-82. doi: 10.1111/j.0954-6820.1974.tb00971.x

4. Marks MI, McLaine PN, Drummond KN. Proteinuria in children with febrile illnesses. Arch Dis Child. (1970) 45:250-3. doi: 10.1136/adc.45.240.250

5. Hemmingsen L, Skaarup P. Urinary excretion of ten plasma proteins in patients with febrile diseases. Acta Med Scand. (1977) 201:359-64. doi: 10.1111/j.0954-6820.1977.tb15712.x

6. Reiser J, von Gersdorff G, Loos M, Oh J, Asanuma K, Giardino L, et al. Induction of B7-1 in podocytes is associated with nephrotic syndrome. J Clin Invest. (2004) 113:1390-7. doi: 10.1172/JCI20402

\section{LIMITATIONS OF THE STUDY}

The study was performed on a relatively small sample of patients, due to budget limitations. Thus, the negative statistically significant differences found between the bacterial and viral groups may become significant in larger study groups. In addition, only a limited number of urinary excreted proteins were analyzed in this study, and the correlation between blood level of these proteins and their excretion was not assessed.

In summary, in this first study we have shown that febrile proteinuria is not a generalized nonspecific phenomenon: while proteins of both glomerular and tubular origin increase, uromodulin decreases. Urine B7-1, a possible marker of increased glomerular permselectivity is increased during fever, more significantly in bacterial infections. Thus, if verified by larger studies, urinary B7-1 may be used as an additional marker to differentiate between febrile states of bacterial and viral origin.

\section{ETHICS STATEMENT}

The research protocol of the study has been approved by the Soroka University Medical Center local Helsinki committee. Study consent was signed by patients' parents.

\section{AUTHOR CONTRIBUTIONS}

EG and EI recruited the patients. EI wrote a preliminary report. EG wrote the manuscript's first draft. YS performed the laboratory analyses and reviewed the manuscript. DL conceived the study design and finalized the manuscript's last version.

\section{ACKNOWLEDGMENTS}

The study was supported by an unconditioned research grant of the Israeli Society of Clinical Pediatrics. No honorarium, grant, or other form of payment was given to anyone to produce the manuscript.

7. Garin EH, Mu W, Arthur JM, Rivard CJ, Araya CE, Shimada M, et al. Urinary CD80 is elevated in minimal change disease but not in focal segmental glomerulosclerosis. Kidney Int. (2010) 78:296-302. doi: 10.1038/ki.2010.143

8. Robin X, Turck N, Hainard A, Tiberti N, Lisacek F, Sanchez JC, et al. pROC: an open-source package for R and $\mathrm{S}+$ to analyze and compare ROC curves. BMC Bioinformatics (2011) 12:77. doi: 10.1186/1471-2105-12-77

9. Hession C, Decker JM, Sherblom AP, Kumar S, Yue CC, Mattaliano RJ, et al. Uromodulin (Tamm-Horsfall glycoprotein): a renal ligand for lymphokines. Science (1987) 237:1479-84. doi: 10.1126/science.3498215

10. Bates JM, Raffi HM, Prasadan K, Mascarenhas R, Laszik Z, Maeda $\mathrm{N}$, et al. Tamm-Horsfall protein knockout mice are more prone to urinary tract infection: rapid communication. Kidney Int. (2004) 65:791-7. doi: 10.1111/j.1523-1755.2004.00452.x

11. Mo L, Zhu XH, Huang HY, Shapiro E, Hasty DL, Wu XR. Ablation of the Tamm-Horsfall protein gene increases susceptibility of mice to bladder colonization by type1-fimbriated Escherichia coli. Am J Physiol Renal Physiol. (2004) 286:F795-802. doi: 10.1152/ajprenal.00357.2003

12. Pak J, Pu Y, Zhang ZT, Hasty DL, Wu XR. Tamm-Horsfall protein binds to typel fimbriated Escherichia coli and prevents E. coli from binding 
to uroplakin Ia and Ib receptors. J Biol Chem. (2001) 276:9924-30. doi: 10.1074/jbc.M008610200

13. Rhodes DC, Hinsman EJ, Rhodes JA. Tamm-Horsfall glycoprotein binds IgG with high affinity. Kidney Int. (1993) 44:1014-21. doi: 10.1038/ki.1993.343

14. Rhodes DC. Binding of Tamm-Horsfall protein to complement 1q measured by ELISA and resonant mirror biosensor techniques under various ionic-strength conditions. Immunol Cell Biol. (2001) 78:474-82. doi: 10.1111/j.1440-1711.2000.t01-3-.x

15. Schmid M, Prajczer S, Gruber LN, Bertocchi C, Gandini R, Pfaller W, et al. Uromodulin facilitates neutrophil migration across renal epithelial monolayers. Cell Physiol Biochem. (2010) 26:311-8. doi: 10.1159/000320554

16. Saemann MD, Weichhart T, Zeyda M, Staffler G, Schunn M, Stuhlmeier KM, et al. Tamm-Horsfall glycoprotein links innate immune cell activation with adaptive immunity via a Toll like receptor-4-dependent mechanism. J Clin Invest. (2005) 115:468-75. doi: 10.1172/JCI200522720

17. Prajczer S, Heidenreich U, Pfaller W, Kotanko P, Lhotta K, Jennings P. Evidence for a role of uromodulin in chronic kidney disease progression. Nephrol Dial Transplant. (2010) 25:1896-903. doi: 10.1093/ndt/gfp748

18. Yu CC, Fornoni A, Weins A, Hakroush S, Maiguel D, Sageshima J, et al. Abatacept in B7-1-positive proteinuric kidney disease. N Engl J Med. (2013) 369:2416-23. doi: 10.1056/NEJMoa1304572
19. Baye E, Gallazzini M, Delville M, Legendre C, Terzi F, Canaud G. The costimulatory receptor B7-1 is not induced in injured podocytes. Kidney Int. (2016) 90:1037-44. doi: 10.1016/j.kint.2016.06.022

20. Takeda K, Kaisho T, Akira S. Toll-like receptors. Annu Rev Immunol. (2003) 21:335-76. doi: 10.1146/annurev.immunol.21.120601. 141126

21. Beutler B, Rietschel ET. Innate immune sensing and its roots: the story of endotoxin. Nat Rev Immunol. (2003) 3:169-76. doi: 10.1038/ nri1004

Conflict of Interest Statement: The authors declare that the research was conducted in the absence of any commercial or financial relationships that could be construed as a potential conflict of interest.

Copyright (C) 2018 Gurevich, Israel, Segev and Landau. This is an open-access article distributed under the terms of the Creative Commons Attribution License (CC BY). The use, distribution or reproduction in other forums is permitted, provided the original author(s) and the copyright owner(s) are credited and that the original publication in this journal is cited, in accordance with accepted academic practice. No use, distribution or reproduction is permitted which does not comply with these terms. 